\title{
Reproduction of Brevoortia aurea (Spix \& Agassiz, 1829) (Actinopterygii: Clupeidae) in the Mar Chiquita Coastal Lagoon, Buenos Aires, Argentina
}

\author{
Nicolás Agustín Lajud ${ }^{1}$, Juan Martín Díaz de Astarloa ${ }^{1,2}$ and Mariano González-Castro ${ }^{1,2}$
}

\begin{abstract}
Reproductive biology of the Brazilian menhaden, Brevoortia aurea (Clupeiformes), was studied in Mar Chiquita Coastal Lagoon. Its abundance was analysed in relation to environmental variables, and the main biological-reproductive parameters were estimated: size at first maturity, batch and relative fecundity, frequency distribution of oocyte diameters and gonadosomatic index (GSI). Moreover, its reproductive cycle was analysed histologically. Samples were collected from May 2012 to April 2013. Once the spawning period was detected, extra samples were added (October and November 2013). The specimens were caught with gillnets, at a distance of 2,300 meters from the mouth of the lagoon. The highest abundances were observed in the months of October and November. Both macroscopic and microscopic analysis allowed to confirm that in these months the saraca spawn in the mixo-eurihaline area of the lagoon. Females were recorded in the five phases of ovarian development. Histological and frequency distribution of oocyte diameters characterized this species as a batch spawner with undetermined fecundity. The fecundity varied between 19,900 and 178,508 oocytes/female. Relative fecundity ranged between 41 and 381 oocytes/g female ovary free. The size at first maturity was estimated on 277 and 265 $\mathrm{mm}$ total length for females and males, respectively.
\end{abstract}

Se estudió la biología reproductiva de la saraca, Brevoortia aurea (Clupeiformes), en la Laguna Costera Mar Chiquita. Se analizó su abundancia, en relación con las variables ambientales y se estimaron los principales parámetros biológicoreproductivos: talla de primera madurez (longitud total), fecundidad parcial y relativa, distribución de frecuencias de diámetros oocitarios e índice gonado-somático (IGS). Además, se analizó su ciclo gonadal desde un aspecto histológico, en función de un ciclo anual. Las muestras se colectaron desde Mayo 2012, hasta Abril 2013. Una vez detectado el período de desove se duplicó el muestreo durante dichos meses (Octubre y Noviembre 2013). Los ejemplares se capturaron con redes de enmalle, a 2.300 metros de la desembocadura de la laguna con el mar. Las mayores abundancias se observaron en los meses de Octubre y Noviembre. Tanto el análisis macroscópico como el microscópico permitieron afirmar que en dichos meses la saraca realiza desoves en la zona mixo-eurihalina de esta laguna. Se registraron hembras en las cinco fases del desarrollo ovárico. Los análisis histológicos y de distribución de la frecuencia de diámetros ovocitarios caracterizaron a esta especie como un desovante parcial con fecundidad indeterminada. La fecundidad parcial varió entre 19.900 y 178.508 oocitos/hembra. La fecundidad relativa varió entre 41 y 381 oocitos/gr hembra libre de ovario. La talla de primera madurez se estimó en 277 y $265 \mathrm{~mm}$ de longitud total para hembras y machos, respectivamente.

Keywords: Clupeiformes, Multiple spawner, Pelagic, Reproduction.

\section{Introduction}

Members of Clupeidae are typically marine, coastal and schooling fishes, found in all seas from $70^{\circ} \mathrm{N}$ to about $60^{\circ} \mathrm{S}$ (Carpenter, 2002). Some species tolerate low salinities, sometimes entering fresh water to feed. Clupeids typically form large schools and generally scatter pelagic eggs that hatch planktonic larvae (Munroe \& Nizinski, 2002). The species of the genus Brevoortia constitute important fisheries and ecological representatives both, on the northwest and southwest Atlantic Oceans (Deegan,
1993; Forward et. al., 1996; Vaughan, 2007). Historically, the existence of two large-scaled Southwestern Atlantic menhaden Brevoortia aurea (Spix \& Agassiz, 1829) and B. pectinata (Jenyns, 1842) have been reported to be occurring from state of Rio Grande do Sul (Brazil) to the Río de la Plata estuary (Whitehead, 1985; Lasta \& Ciechomski, 1988). However, Cousseau \& Díaz de Astarloa (1993), Segura \& Díaz de Astarloa (2004) and García et al. (2008) concluded that $B$. aurea (locally called as "saraca") is the only species of the genus inhabiting the Southwestern Atlantic Ocean.

${ }^{1}$ Laboratorio de Biotaxonomía Morfológica y Molecular de Peces (BIMOPE). Instituto de Investigaciones Marinas y Costeras, IIMyCCONICET- UNMdP. Mar del Plata, Buenos Aires, Argentinga. (NAL) nicolaslajud@gmail.com

${ }^{2}$ Consejo Nacional de Investigaciones Científicas y Técnicas (CONICET). (JMDA) astarloa@mdp.edu.ar, (MGC) gocastro@mdp.edu.ar (corresponding author). 
Brevoortia aurea is an estuarine-dependent, pelagic, coastal species, inhabiting shallow nursery areas for their early development, which is capable to perform migrations between the sea and estuaries (Cousseau \& Díaz de Astarloa, 1993; González-Castro et al., 2009a; Cousseau et al., 2011). As a filter feeder, the species has a key position between the primary producers and the secondary consumers on the trophic chain. High densities of Brazilian menhaden eggs and larvae have been documented (Bruno et al., 2013) when the spawning events take place, as well as high densities of juvenile when the recruitment occur in estuaries (Gonzales-Castro et al., 2009a). Also, B. aurea could lend an important role in the exchange of organic matter between the freshwater environment and the sea, as B. patronus Goode, 1878 does in the Northewestern Atlantic (Deegan, 1993; Garman \& Macko, 1998). This fact could bring more importance to $B$. aurea resource, in order to decrease the captures of other exploited species, and to present an alternative use of these species on the fish flour industries.

The reproductive studies of $B$. aurea performed in Argentina are scarce. Fecundity estimations have been performed on Mar del Plata coast (Cassia et al., 1979) and the spawning frequency and batch fecundity was estimated (Macchi \& Acha, 2000) for the Rio de la Plata estuary. So far, no studies related to the life cycle (based on monthly samples during an annual cycle) of adults specimens of this species, have been carried out in Argentina.

Fish composition of Mar Chiquita has been widely studied and is well known that this lagoon has a crucial role in the life cycles of many fish species, as a scale on migratory routs, refugee from storms, feeding and nursery area of some commercially and ecologically important species, as well as exotic invasive species (González-Castro et al., 2009b, 2013, 2015). From a total of 28 reported fish species, B. aurea represented the most abundant species in Mar Chiquita coastal lagoon (González-Castro et al., 2009a). High densities of $B$. aurea specimens in the inner zone of Mar Chiquita lagoon were correlated with mature/ripe ovaries, as revealed by sexual maturity stage analysis. This strongly suggests that reproductive events should occur in the northern zone of Mar Chiquita. However, these observations were analyzed only macroscopically and no reproductive studies, related to the life cycle of the adult stock based on an annual cycle have previously been carried out for this species. Moreover, neither estimations of size at first maturity nor monthly GSI mean values have been previously reported for this species.

In this context, the main aim of the present paper was to study the life cycle of $B$. aurea in a shallow estuarine environment, the Mar Chiquita Coastal Lagoon (Argentina). We tested the hypothesis that B. aurea reproduce within Mar Chiquita coastal Lagoon. Our objectives were: (1) to analyze the monthly abundance and their relationship with environmental variables, (2) to perform histological analysis of ovarian development and describe the stages of oocyte development and (3) to estimate the main biological-reproductive parameters for the stock of $B$. aurea that inhabits Mar Chiquita lagoon (frequency of oocyte diameter distribution, batch fecundity, length at first maturity $\left(\mathrm{L}_{50}\right)$ and gonadosomatic index).

\section{Material and Methods}

Study area. Mar Chiquita Coastal Lagoon (37 $32^{\prime}$ S, $57^{\circ} 19^{\prime} \mathrm{W}$, Argentina) is a shallow estuary (0.4-3 m deep) of $25 \mathrm{~km}$ large and 5,850 ha, separated from the sea by a littoral line of dunes, and connected to it by an inlet channel (Isla, 1995). It is considered a World Biosphere Reserve by the Man and Biosphere Program (MaB) of UNESCO (Iribarne, 2001). The semidiurnal tidal regime affects both depth and salinity in the lagoon. Mean depth is $1.20 \mathrm{~m}$, with a maximum of $4.90 \mathrm{~m}$ at high tide and a minimum of $0.80 \mathrm{~m}$ at low tide. Salinity has a horizontal gradient that fluctuates between 0 and 36, depending on tide and wind (Reta et al., 2001). Water temperature varies monthly and two seasons can be identified: the warm season (October to March), with water temperatures between 13 and $21^{\circ} \mathrm{C}$, and the cold season (April to September), with temperatures between 6 and $13^{\circ} \mathrm{C}$ (Cousseau et al., 2001; Reta et al., 2001).

Fish samples. Specimens of $B$. aurea were collected monthly between May 2012 and April 2013 in the inlet channel of the lagoon (Fig. 1). Voucher specimens (UNMdP 2332 and UNMdP 2333) were deposited in the Fishes Collection of the Instituto de Investigaciones Marinas y Costeras (IIMyC; CONICET- UNMDP), Argentina. Once detected the reproductive period of this species, extra samples were added on October and November 2013 in order to increase the number of samples used for the reproductive parameters estimation.

Four $25 \mathrm{~m}$ long, $1.5 \mathrm{~m}$ high monofilament gill nets, with $51 \mathrm{~mm}, 68 \mathrm{~mm}, 120 \mathrm{~mm}$ and $130 \mathrm{~mm}$ mesh sizes were employed. Environmental variables (water temperature $\left({ }^{\circ} \mathrm{C}\right)$, salinity (practical salinity units (psu)), and turbidity (nephelometric turbidity units (ntu)) were recorded with an Horiba ${ }^{\circledR}$ multiparameter. The specimens were taxonomically identified following Cousseau et al. (2011) and Cousseau \& Perrota (2013). Total length (TL) was recorded to the nearest $\mathrm{mm}$. Total weight (TW) and ovary weight $(\mathrm{OW})$ were recorded to $0.1 \mathrm{~g}$ with an electronic balance.

A macroscopic and microscopic maturity scale of five phases was employed according to Brown-Peterson et al. (2011), as follows: 1-immature, 2-developing, 3-spawning capable (which includes a sub-phase of actively spawning), 4-regressing and 5-regenerating. Weighed ovaries were stored $12 \mathrm{~h}$ in Davidson solution, and preserved in ethanol $70^{\circ} \mathrm{GL}$ for the subsequent laboratory analysis. 


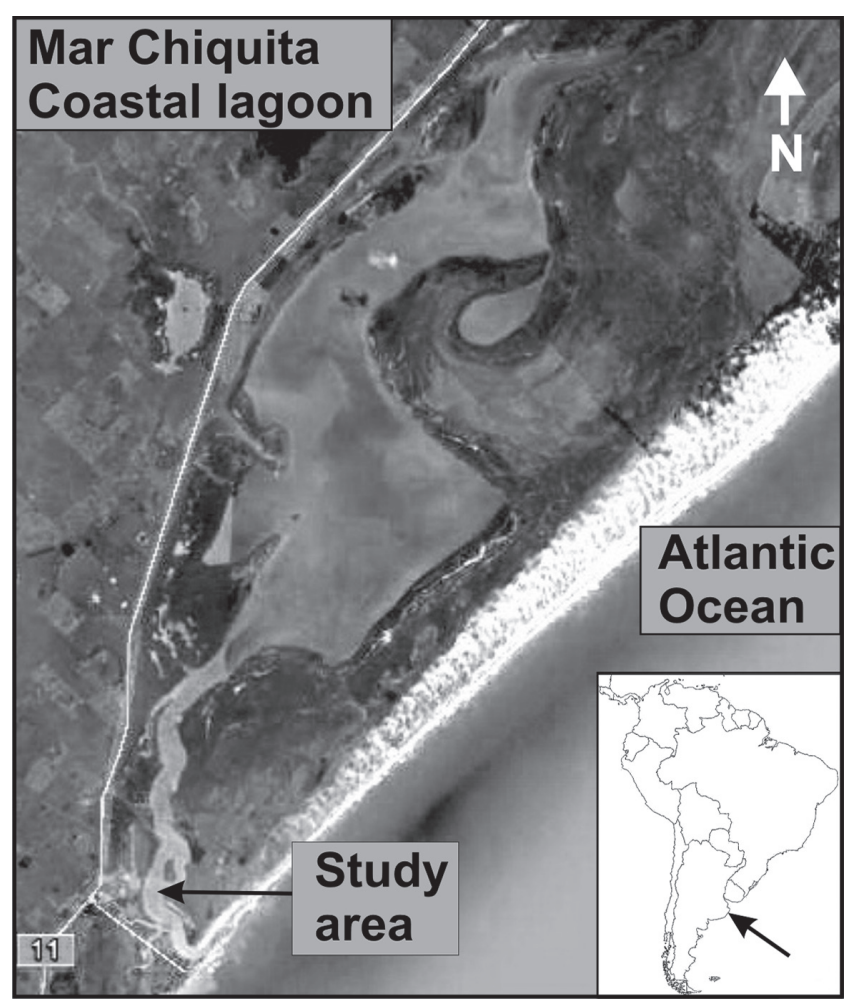

Fig. 1. Study area showing the sample station.

Gonad analysis. A piece of tissue from the stored ovaries was removed, dehydrated in ethanol $100^{\circ} \mathrm{GL}$, cleared in xylol and embedded in paraffin. Sections were cut at 5 $\mu \mathrm{m}$ and stained with Harry's haematoxylin followed by eosin counterstain as in González-Castro et al. (2011). Histological classification of ovaries was based on oocyte development stage (Brown-Peterson et al., 2011).

Oocyte diameter frequency distribution. Soon after fixation, 30 ovaries in actively spawning sub-phase (according to Brown-Peterson et al., 2011) were stored in ethanol $70^{\circ}$ GL. A total of 200 oocytes per ovary were removed, placed in water, and the longest axis was measured with an ocular micrometer. The oocyte diameter frequency was plotted.

Fecundity estimation and Gonadosomatic Index (GSI\%). Batch fecundity (number of oocytes released per spawning) was estimated employing 34 ovaries in spawning capable maturation phase (actively spawning sub-phase), stored in ethanol $70^{\circ} \mathrm{GL}$ after fixation. These ovaries were characterized by hydrated oocytes and showed no evidence of recent spawning (no post ovulatory follicles were observed). Three portions (of approximately $0.1 \mathrm{~g}$ ) of the anterior, medial and posterior parts of the gonad were rehydrated, weighed with an analytical balance $(0.0001 \mathrm{~g})$ and all hydrated oocytes were counted. Batch fecundity was estimated according to Hunter et al. (1985). Relative fecundity (number of hydrated oocytes per gram of ovaryfree body weight) was calculated as the batch fecundity divided by female weight (ovary-free) (Hunter et al., 1985).
The relationship of batch fecundity to total length and total weight (ovary free); and relative fecundity to total length and total weight (ovary free), were described using the Pearson correlation method (Kartas \& Quignard, 1984). The GSI was estimated as the ovary weight divided by body weight (x 100). It was analyzed in relation to the annual cycle and maturity phases.

Abundance analysis. Capture per unit effort (CPUE) in $\mathrm{kg} / \mathrm{h}$, was plot against environmental variables. Monthly fish abundance variability, related with environmental variables, was analyzed using the generalized linear models (GLMs) (Venables \& Ripley, 2002). The models were built with the monthly number of captured fishes, as the response variable, and the environmental variables (temperature, salinity and turbidity), season of the year (summer, autumn, winter and spring) and the monthly average of GSI, as independent variables. As data show over dispersion and many zero values, a negative binomial error distribution and log link were specified (Crawley, 2005). Model parameters were obtained by maximizing the maximum likelihood (Crawley, 2005).

The models were built with each variable mentioned above and combinations of those variables. Also, a null model with no variable was built, in order to test the hypothesis that none of the tested variables had effect on the observed abundances. The best model was selected, by using the Akaike Information Criterion (AIC), as the model with the lowest AIC (Franklin et al., 2001). Each model was weighed against the others using the Akaike weights, which gives an estimation of the likelihood of the model's fit according to the employed data (Anderson et al., 2000; Franklin et al., 2001; Johnson \& Omland, 2004).

Length at first maturity $\left(\mathbf{L}_{\mathbf{5 0}}\right)$. The maturity phase of 588 females and 293 males were determined. Individuals were grouped in $5 \mathrm{~mm}$ length classes, and classified as immature (juveniles) (Phase 1) or mature (adults) (Phases 2 to 5). A logistic model was fitted to the proportion of mature individuals by total length class, using the maximum likelihood method (Roa et al., 1999).

\section{Results}

A total of 633 females and 321 males was collected during the sampled period, with a size range of $132-420 \mathrm{~mm}$ (mean=328 $\mathrm{mm}$ ) and 148-403 $\mathrm{mm}$ (mean=291), respectively.

Environmental variables and capture per unit effort (CPUE). Specimens of B. aurea captured in this study tolerated wide range of salinities, from almost fresh ( $0.7 \mathrm{psu})$ to full-strength sea water (33 psu). Remarkably, salinity did not show a seasonal pattern, as well as the turbidity ( 0.86 to $90.2 \mathrm{ntu}$, data not shown). Conversely, water temperature varied seasonally, showing the lowest value in winter (5.35 ${ }^{\circ} \mathrm{C}$ ), and the highest one in summer $\left(26.19^{\circ} \mathrm{C}\right)$ (Fig. 2). 
The lowest abundances (estimated by CPUE) were registered in winter. Particularly, no captures were recorded in June, July and August. The highest CPUE values were recorded in October, and November (Fig. 2).

Generalized linear models. Thirteen models were tested in order to explain the observed abundances (Table 1). The model involving the water temperature and the GSI was the best one with an AIC of 37.1, followed by the one involving the season and the GSI (AIC 39.1). It is noticeable that the months in which the lowest temperature was recorded were correlated with the lowest abundance values. In contrast, the highest temperature values were not correlated with the highest abundance values.

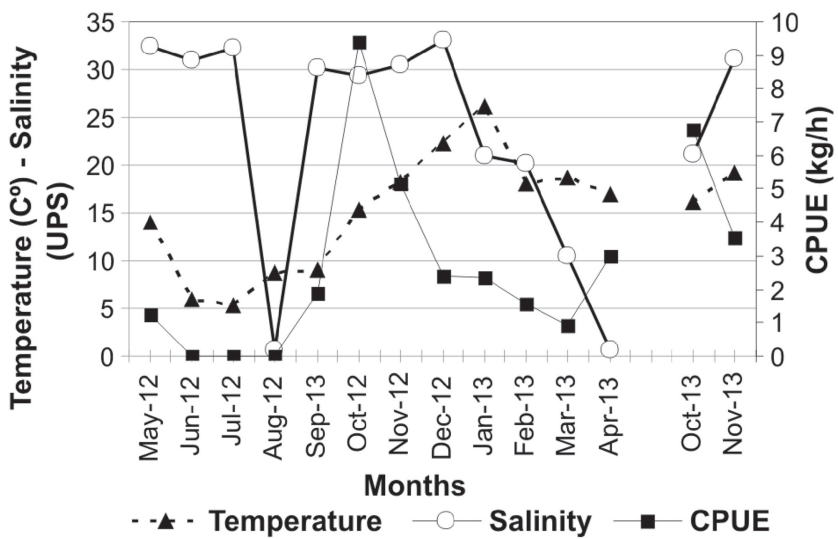

Fig. 2. Captures per unite effort (CPUE $\mathrm{kg} / \mathrm{h}$ ), temperature $\left({ }^{\circ} \mathrm{C}\right)$ and salinity (psu) obtained for Brevoortia aurea during sampled period in Mar Chiquita Coastal Lagoon.

Gonadosomatic index (GSI). The ANOVA test showed significant differences for the mean-GSI values for each ovaric maturity Phase $\left(\mathrm{P}=5.34 \times 10^{-4} ; \mathrm{F}=14.72\right)$. The mean GSI reached its highest values in October (13.9) and November (12.1) 2013, and gradually decreases with a minimum mean GSI value of 2.3 in March (Fig. 3).

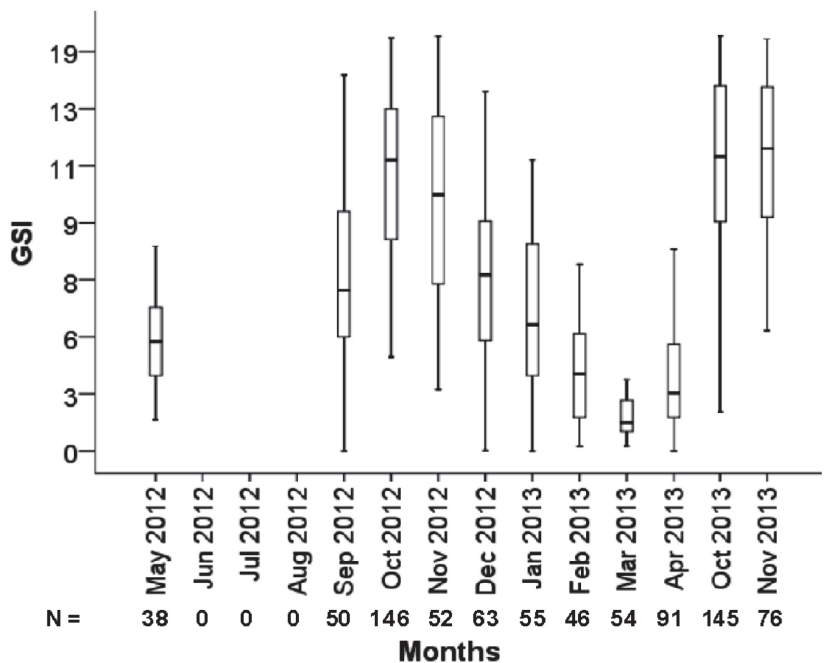

Fig. 3. Monthly variation of the gonadosomatic index (GSI) (females only), based on an annual cycle.
Table 1. Competing models for explaining the abundances of Brevoortia aurea in Mar Chiquita coastal lagoon.

\begin{tabular}{lcccc}
\hline Model & AIC & df & $\Delta$ AIC & w \\
\hline$\sim$ Null & 52.5 & 2 & 15.4 & $<0.001$ \\
$\sim$ Temperaturature (Temp) & 51.9 & 3 & 14.8 & $<0.001$ \\
$\sim$ Salinity (Sal) & 53.9 & 3 & 16.7 & $<0.001$ \\
$\sim$ Turbidity (Turb) & 54 & 3 & 16.9 & $<0.001$ \\
$\sim$ Season & 42.3 & 5 & 5.2 & 0.0484 \\
$\sim$ Sal+Turb & 55.7 & 4 & 18.6 & $<0.001$ \\
$\sim$ Temp+Sal & 52.7 & 4 & 15.6 & $<0.001$ \\
$\sim$ Season+Temp & 42.4 & 6 & 5.3 & 0.0446 \\
$\sim$ Temp+Turb & 53.1 & 4 & 16 & $<0.001$ \\
$\sim$ Temp+Sal+Turb & 53.1 & 5 & 16 & $<0.001$ \\
$\sim$ Temp+GSI & $\mathbf{3 7 . 1}$ & $\mathbf{4}$ & $\mathbf{0}$ & $\mathbf{0 . 6 4 2 9}$ \\
$\sim$ Season+GSI & 39.1 & 5 & 1.9 & 0.2432 \\
$\sim$ Temp+Sal+Turb+Season+GSI & 44.1 & 8 & 7 & 0.0193 \\
\hline
\end{tabular}

Ovarian cycle. Five ovaric phases were recorded. Immature individuals (Phase 1) were recorded mostly between February and April. Phases 2 (development) and 3 (spawning capable) were recorded in almost all sampled months. The most advanced maturity phase (Active spawning sub-phase) appears in $20 \%$ of the individuals captured in October and November 2013. The regressing phase appears in October and November 2013 during the reproductive events, as expected considering the batch spawning strategy of this species (Fig. 4). The regenerating phase was observed only in December, after the registered reproductive events.

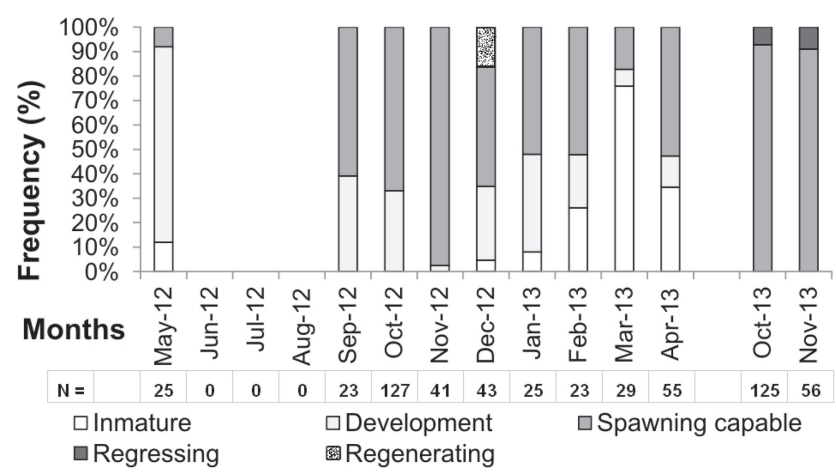

Fig. 4. Monthly relative frequency of the different gonadal development stages observed in females of Brevoortia aurea on the annual cycle, and the added samples of October and November for the Mar Chiquita coastal lagoon.

Description of maturity phases and frequency of occurrence during the sample period. 1). Immature. This phase is characterized by very small pink ovaries, with a thin tunic. Only previtelogenic oocytes are present. This stage was observed in February, March and April; 2). Development. This phase was found in all of the annual cycle months, without the winter ones. The ovaries increase their sizes, the blood vessels, cortical alveoli oocytes and primary vitelogenesis oocytes become visible; 3 ). Spawning capable. The ovaries are yellow, occupy almost one third of 
the abdominal cavity. Ovarian arteries and its ramifications appear, and the oocytes are macroscopically visible (mostly yolked oocytes). This phase was observed in all of the sampled months. In the sub-phase actively spawning, the ovaries occupy approximately the half of the abdominal cavity, they become highly ramified and in orange color. The tunic gain turgidity, and the oocytes reach the largest size (hydrated oocytes, one mm approximately). This phase was found only in the reproductive months of October and November; 4). Regressing. The flaccid ovaries, with gross tunics, appear in red color because of the blood spill due to the recent spawning activity. Primary grow, cortical alveoli and yolked oocytes are present, as well as postovulatory follicles (POF's) and atresia. This phase was found in October and November 2013; 5). Regenerating. The ovaries, in yellow, decrease their sizes, recover turgidity and the tunic remains gross. Only primary grow oocytes and oogonias are present. This phase was observed only in December.

Stages of oocyte development. During the analyzed period, the following stages were observed: A-Oogonias, B-Primary growth oocyte, C-Cortical alveolus stage, D-Yolked oocytes, E-Hydrated oocytes, F-Atresic follicles and G-Post-ovulatory follicles (POFs). (Table 2; Fig. 5).

Frequency distribution of oocyte diameters. The size diameter distribution of formalin preserved oocytes on actively spawning ovaries was tetramodal (Fig. 6). The smallest group refers to primary growth oocytes, with sizes of 50 to $150 \mu \mathrm{m}$. The second one was constituted by cortical alveoli stage oocytes, and ranged between 150 and 350 $\mu \mathrm{m}$. The third group was composed by the yolked oocytes, which ranged between 350 and $750 \mu \mathrm{m}$ and the last one corresponded to the final development oocytes (hyaline and hydrated oocytes) with diameters from 750 to $1,600 \mu \mathrm{m}$.

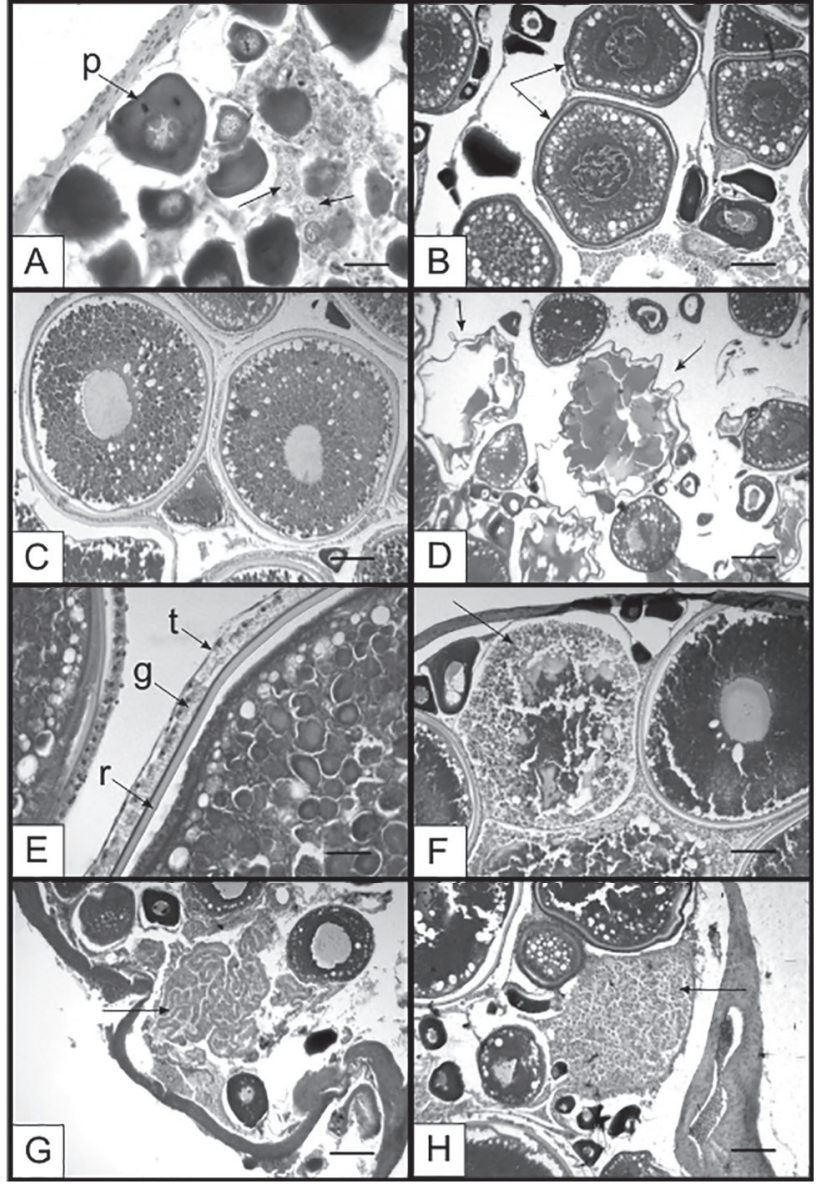

Fig. 5. A: oogonias (arrow) and primary growth (p) oocytes; B: cortical alveoli stage oocyte (arrow); C: yolked oocytes; D: hydrated oocytes (arrow); E: details of a yolked oocyte (r: radiata zone; g: granulosa cells; t: teca cells); F: atresic follicle (arrow); G: post-ovulatory follicle "0" (arrow); H: post-ovulatory follicle "1" (arrow). Scale bars: A, E $25 \mu \mathrm{m}$; B, C, F, G, H, $100 \mu \mathrm{m} ; \mathrm{D}, 250 \mu \mathrm{m}$.

Table 2. Descriptions of each stage of oocyte development, atretic and post-ovulatory follicles.

\begin{tabular}{|c|c|}
\hline Stage & Microscopic characteristic \\
\hline A. Oogonias & $\begin{array}{l}\text { Small cells, with approximately } 10 \mu \mathrm{m} \text { diameters. Large nucleus of central location, with lax chromatin, surrounded by } \\
\text { scarce basophilic cytoplasm. }\end{array}$ \\
\hline B. Primary growth oocytes & $\begin{array}{l}\text { With a size between } 50 \text { to } 200 \mu \mathrm{m} \text {, this cells has basophilic cytoplasm and a large nucleus of central location with some } \\
\text { nucleoli at the periphery. }\end{array}$ \\
\hline C. Cortical alveolus & $\begin{array}{l}\text { With diameters between } 200 \text { and } 350 \mu \text { m and a nucleus of approximately one third of the cell diameter. Vesicles located } \\
\text { on the cell periphery, called "cortical alveoli", characterize this stage. The cytoplasm is basophilic, the radiata zone is } \\
\text { visible (highly eosinophilic), as well as the follicular layer (granulosa and teca cells). }\end{array}$ \\
\hline D. Yolked oocytes & $\begin{array}{l}\text { Oocytes increased their diameters from } 350 \text { to } 750 \mu \mathrm{m} \text {. Yolk granules (with eosinophilic affinity) are present in the } \\
\text { cytoplasm due to the exogenous vitellogenesis. Although less frequent, lipid vesicles are observed disperse between } \\
\text { the yolk granules. Radiate zone (highly eosinophilic) and the follicular cells reach their maximum development. The } \\
\text { nucleus continues in central position. }\end{array}$ \\
\hline E. Hydrated oocytes & $\begin{array}{l}\text { With a size range from } 750 \text { to a } 1600 \mu \mathrm{m} \text {. Germinal vesicle migration (GVM) and break down (GVBD) of nuclear } \\
\text { membrane are the previous steps to the cytoplasmic hydration, were the cellular size increases notoriously. Hydrated } \\
\text { oocytes displayed an irregular shape, due to the alcohol dehydration performed at the histological procedures. }\end{array}$ \\
\hline F. Atretic follicles & $\begin{array}{l}\text { Disintegration and reabsorption of the oocytes by the follicular cells, from the periphery to the center. Most are observed } \\
\text { at the end of the reproductive cycle and occur mostly on yolked and hydrated oocytes. }\end{array}$ \\
\hline G. Post-ovulatory follicles (POFs) & $\begin{array}{l}\text { After ovulation, the remaining follicular cells form an irregular shape in the ovary tissue. The follicular lumen size } \\
\text { decreased and the degradation increased according to the time since ovulation. }\end{array}$ \\
\hline
\end{tabular}




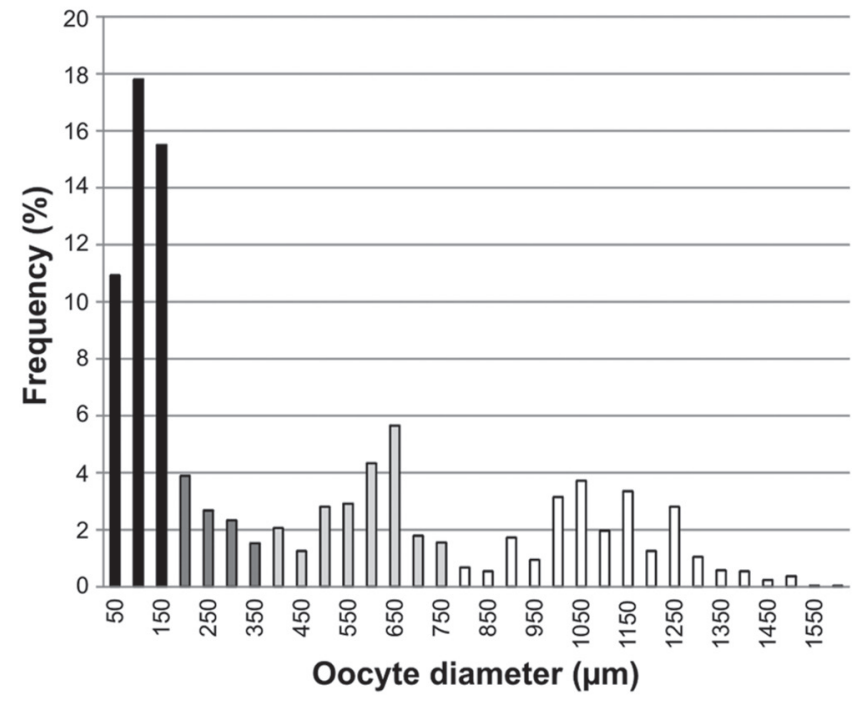

Fig. 6. Frequency distribution of oocyte diameters $(N=$ 6000 oocytes measured). From black bars to white bars: Primary growth oocyte, cortical alveoli, yolked oocytes and hydrated oocytes.

Fecundity. Batch fecundity estimates ranged between 19,900 and 178,508 hydrated oocytes, corresponding to females with 353 to $357 \mathrm{~mm}$ TL, respectively. Unexpectedly, no significant $r^{2}$ and Pearson correlation were found between the batch fecundity, against TL and the TW ovaryfree values (Fig. 7 A, B).
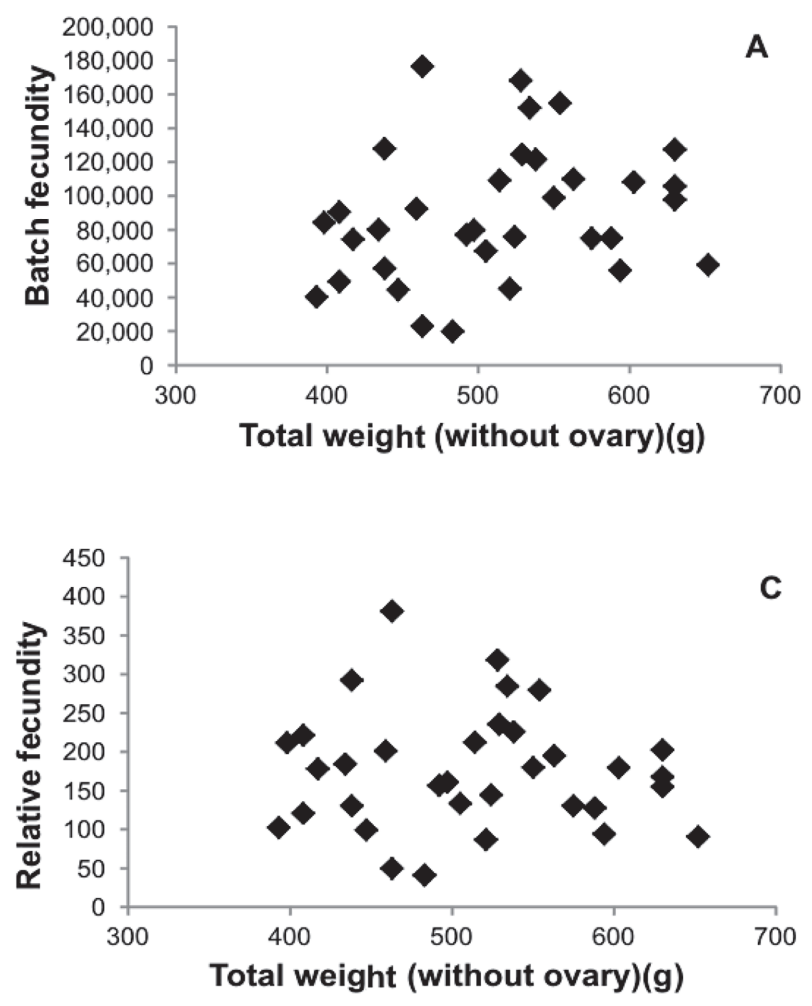

Relative fecundity estimates ranged between 50 to 381 oocytes per gram of female, for 353 and $357 \mathrm{TL}$, respectively. Again, no significant $r^{2}$ and Pearson correlation were found (Fig. 7 C, D).

Length at first maturity $\left(\mathbf{L}_{50}\right)$. The $\mathrm{L}_{50}$ estimated values were $278 \mathrm{~mm}$ TL and $266 \mathrm{~mm}$ TL for females and males, respectively. A $100 \%$ of maturity was attained at $340 \mathrm{~mm}$ TL and $310 \mathrm{~mm}$ TL for females and males, respectively (Fig. 8).

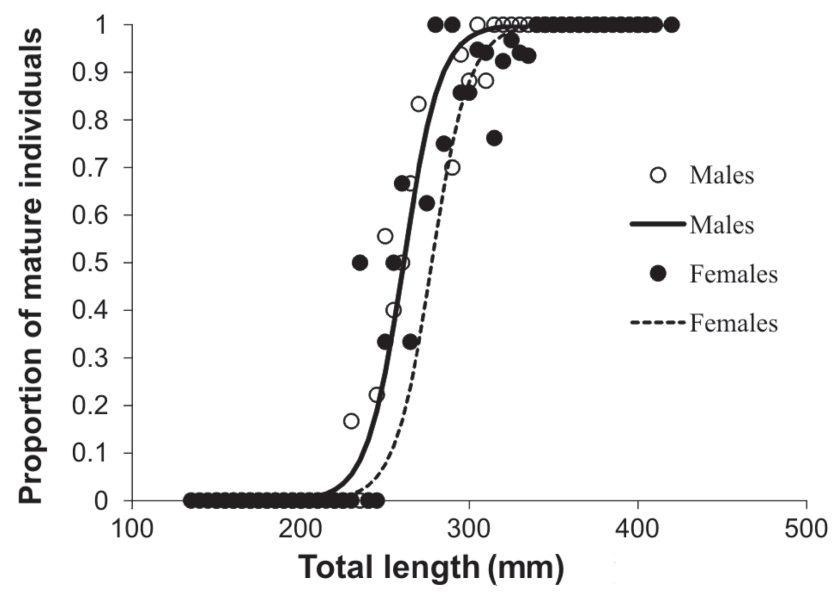

Fig. 8. Proportion of mature individuals observed for each length classes of Brevoortia aurea. Females (black circles, dotted line) $\mathrm{L}_{50}=27.77 \mathrm{~cm}, N=588$. Males (white circles, solid line) $\mathrm{L}_{50}=26.59 \mathrm{~cm}, N=293$.
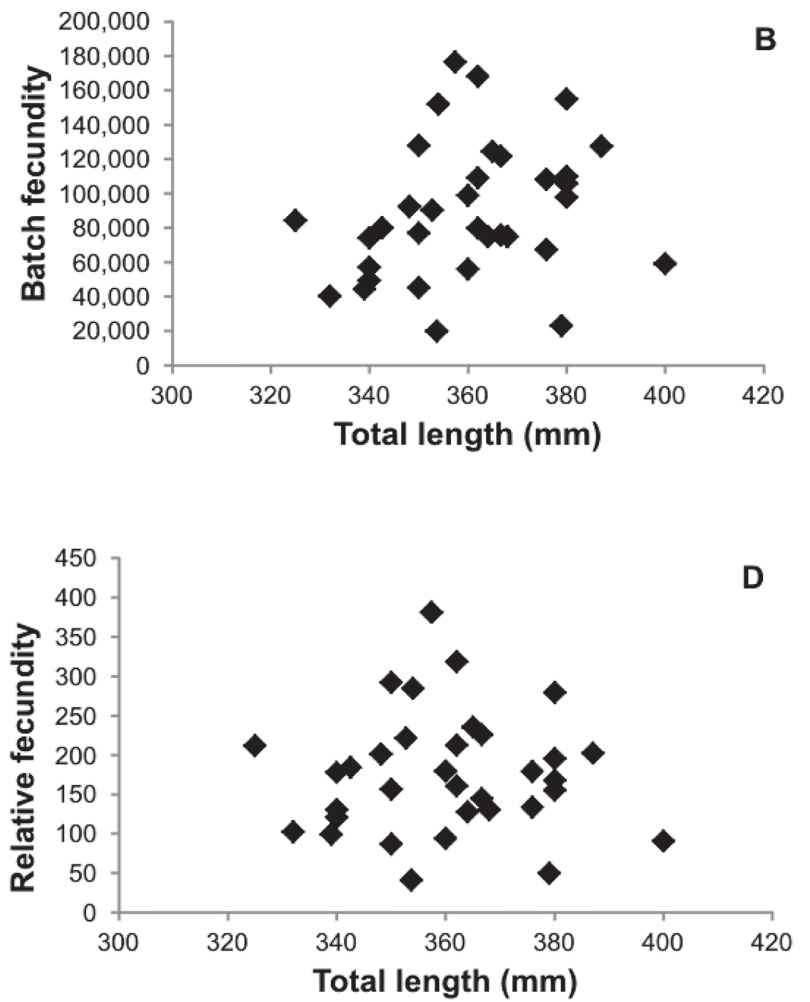

Fig. 7. A and B: Batch fecundity as a function of total weight (without ovary) and total length, respectively. C and D: Relative fecundity as a function of total weight (without ovary) and total length respectively. 


\section{Discussion}

Fish composition of Mar Chiquita coastal lagoon has been recently analysed (González-Castro et al., 2009a). The authors recorded the presence of high densities of $B$. aurea in spring/summer correlated with mature/ripe ovaries, as was revealed by sexual maturity stage analysis performed at macroscopic level. They suggested that reproductive events should occur in the northern zone of this lagoon. They found adult specimens in the four sampled seasons during 20052006, concluding that this species was the most abundant of Mar Chiquita Coastal Lagoon, representing the $65.0 \%$ of the total number of specimens sampled. Moreover, the authors found high densities of early juveniles in summer and autumn. Furhermore, Bruno et al. (2013) reported high density of eggs and larvae of $B$. aurea, in Zone I (sensu González-Castro et al., 2009a), which basically is the sample site of the present study. Here, B. aurea was collected in Mar Chiquita lagoon almost every month (with the exception of June, July and August). During October and November, males and females in actively spawning sub-phase (hydrated oocytes) were found, indicating that reproductive events take place in this lagoon. Similarly, Cassia et al. (1979) reported that the spawning season of the Brazilian menhaden in Mar del Plata coast takes place mainly between October and December.

Although specimens of $B$. aurea captured in this study tolerate a wide range of salinities (0.7-33 psu), the GLM showed that salinity does not explain the registered abundances. In contrast, temperature with the addition of the mean monthly GSI, explained $64 \%$ of the observed abundances. This suggests that the highest abundances of $B$. aurea adult specimens in Mar Chiquita Lagoon are correlated with its highest GSI values (which occur from September to November). Curiously, the highest temperatures were not positively correlated with highest abundances, as also was demonstrated for the grey mullet (Mugil liza) (GonzálezCastro, 2011). Conversely, the lowest temperatures were correlated with the lowest abundances of $B$. aurea recorded for the present paper. Moreover, González-Castro et al. (2009a) found no records of adults specimens of $B$. aurea in the inner zone of Mar Chiquita coastal Lagoon: this data support the results of the present paper (no records of adult specimens in winter in the inlet channel of the lagoon have been found), suggesting that adult specimens migrate from the lagoon to the sea (between June to August) when the water temperature decreases below the physiological tolerance level of the species. Similar results have been observed by Lopez-Cazorla (1985) for the estuary of Bahía Blanca, Argentina, where adult specimens enter the bay in spring to reproduce and migrate offshore at the end of summer.

Our results indicated that the reproductive events of B. aurea were performed at temperatures between 15 and $19{ }^{\circ} \mathrm{C}$, and a salinity range from 21 psu to 31 psu. Macchi \& Acha (2000) reported hydrated females at higher temperatures $\left(19\right.$ and $\left.21^{\circ} \mathrm{C}\right)$ and lower salinities (10 to 25 psu) than those recorded in the present work. Similarly, the Atlantic menhaden B. tyrannus presented the highest percentages of spawning between 17 and $20^{\circ} \mathrm{C}$ (Fitzhugh \& Hettler, 1995).

Frequency distribution of oocyte diameters and histological analysis evidenced the batch spawning behavior of this species. All the stages of oocyte development were found in a single "actively spawning" ovary. Each stage of oocyte development was correlated with a different modal group of the analysis.

Batch fecundity values estimated (19,900 to 178,508 oocytes) are quite similar than those estimated by Macchi \& Acha (2000) (20,000 to 130,000 oocytes). These values are much greater than those of the most important local species of Clupeiformes with similar reproductive strategies. For example, batch fecundity estimated of Anchoa marinii was 749 to 3,207 oocytes, (López et al., 2013). Rodrigues et al. (2008) reported a batch fecundity of 570-2,026 oocytes for Ramnogaster arcuata specimens. Pájaro et al. (1997) reported a fecundity of 13,675 oocytes (+/- 856) for Engraulis anchoita. However, when comparing the relative fecundity of these species, it is noticeable that $B$. aurea presented the lowest values in comparison with those of the above mentioned species: 41-381 hydrated oocytes per gram of female (ovary free) for $B$. aurea, 127-422 oocytes for $A$. marinii (López et al., 2013); R. arcuata between 150 and 437 oocytes (Rodrigues et al., 2008) and E. anchoita with 574 oocytes (Pájaro et al., 1997). These differences could be due to the largest size of the hydrated oocytes of $B$. aurea (1000 to $1600 \mu \mathrm{m}$ in this paper), in comparison with other local species of Clupeiformes (A. marinii; $R$. arcuata and $E$. anchoita) which are less than $1000 \mu \mathrm{m}$ (Rodrigues et al., 2008; López et al., 2013; Pájaro et al., 1997). The size and number of eggs produced vary greatly among species and all of these traits have important consequences for survival. Egg is positively related to the duration of the incubation period and the size of the larva. The greater amount of yolk in large eggs provides more total energy for growth, resulting in larger larvae at hatching and at first feeding. This yields several vital benefits: 1) larvae emerge with a better fitness of behavioural and physiological capabilities than less developed larvae from smaller eggs; 2) they are more resistant to starvation because weight-specific metabolic rates are lower and bodily energy stores are greater; and 3) the larval period is shorter (Fuiman, 2002).

Fecundity values showed a great variation between females of $B$. aurea of similar lengths of the present study. Also, no significant correlation was found between the fecundity and the variables "weight" and "length". This fact was reported by Macchi \& Acha (2000) for this species, but also for other species of Clupeiformes with similar reproductive strategies (López et al., 2013). The females used in this work correspond to the asymptote of infinity length, of the growth curve of Lopez-Cazorla (1985). Therefore, different cohorts are overlapped on similar 
lengths classes. Considering that the fecundity is influenced by the age (Nikolsky, 1963; Begenal, 1973; Hempel, 1979), this fact could explain part of the observed dispersion. An integrative age and fecundity analyses should be necessary to strongly sustain this hypothesis.

There is no previous estimation of the $\mathrm{L}_{50}$ value for $B$. aurea. Cassia et al. (1979) report the minimal length at maturity for this species as $22.5 \mathrm{~cm}$ TL. The present paper shows the first estimates of $\mathrm{L}_{50}$ for the species $(27.77 \mathrm{~cm} \mathrm{TL}$ for females and $26.59 \mathrm{~cm}$ TL for males).

In conclusion, these results exposed above strongly suggest that $B$. aurea reproduce within the Mar Chiquita Coastal Lagoon, and that adults specimens occur during all year long, being scarce during the winter, season in which the Brazilian menhaden probably migrates to adjacent coastal waters with higher temperature than those of Mar Chiquita lagoon. Future studies will be necessary in order to evaluate the role that plays the marine environment in the life cycle of this stock.

\section{Acknowledgements}

The authors would like to thank: Juliana Giménez (CONICET) and Alejandro Sicardi, for technical assistance in the histological procedures; Marcelo Pons, for logistical support; Julio Mangiarotti (forest guard in the Mar Chiquita Biosphere Reserve) and the Mar Chiquita coastal lagoon authorities (Jorge Paredi, Luis Facca, Mónica Iza, Florencia Celesia and Gladys Eiras). Matías Delpiani, Damián Castellini, Valeria Gabbanelli and Martín Vázquez for helping in collecting specimens. This work was supported by UNMdP 15/E525, EXA 577/2 and UNMdP 15/E619, EXA 669/14 grants, but also personal funds of MGC.

\section{References}

Anderson, D. R., K. P. Burnham \& W. L. Thompson. 2000. Null hypothesis testing: problems, prevalence, and alternative. Journal of Wildlife Management, 64: 912-923.

Bagenal, T. N. 1973. Fish fecundity and its relationship with stockand recruitment. Rapports et procès-verbaux des réunions / Conseil permanent international pour l'exploration de la mer, 164: 186-198.

Brown- Peterson, N. J., D. M. Wyanski., F. Saborido- Rey, B. J. Macewicz \& S. K. Lowerre-Barbieri. 2011. A Standardized Terminology for Describing Reproductive Development in Fishes. Marine and Coastal Fisheries: Dynamics, Management, and Ecosystem Science, 3: 52- 70.

Bruno, D. O., S. A. Barbini, J. M. Díaz de Astarloa \& P. Martos. 2013. Fish abundance and distribution patterns related to environmental factors in a choked temperate coastal lagoon (Argentina). Brazilian Journal of Oceanography, 61: 43-53.

Carpenter, K. E. (Ed.). 2002. The living marine resources of the Western Central Atlantic. Volume 2: Bony fishes part 1 (Acipenseridae to Grammatidae). FAO Species Identification Guide for Fishery Purposes and American Society of Ichthyologists and Herpetologists Special Publication No. 5. Rome, FAO, 2: 601-1374.
Cassia, M. C., J. D. de Ciechomski, \& H. E. Christiansen. 1979. Estudios sobre la reproducción y fecundidad de la saraca, Brevoortia aurea (Agassiz, 1829) Hildebrand, 1948 (Pisces. Clupeidae) y la comparación de dos métodos utilizados. Physis, 94: 39-46.

Cousseau, M. B. \& J. M. Díaz de Astarloa. 1993. El género Brevoortia en la costa Atlántica Sudamericana. Frente Marítimo, 14: 49-57.

Cousseau M. B, J. M. Díaz de Astarloa \& D. E. Figueroa. 2001. La Ictiofauna de la Laguna Mar Chiquita. Pp. 187-203. In: Iribarne, O (Ed.). Reserva de Biosfera Mar Chiquita: Características físicas, biológicas y ecológicas. Mar del Plata, Argentina. Editorial Martín.

Cousseau, M. B., M. C. Marchesi, J. M. Díaz de Astarloa \& M. González-Castro. 2011. The ichthyologic relationship between the Mar Chiquita coastal lagoon and the adjacent sea. Historia Natural, 1: 85-100.

Cousseau, M. B. \& Perrotta, R. G. 2013. Peces marinos de Argentina: biología, distribución, pesca. 4. ed.. Mar del Plata, INIDEP, $193 \mathrm{p}$.

Crawley, M. J. 2005. Statistics: an introduction using R. Wiley, $327 \mathrm{p}$.

Deegan, L. A. 1993. Nutrient and energy transport between estuaries and coastal marine ecosystems by fish migration. Canadian Journal of Fisheries and Aquatic Sciences, 50: 74-79.

Fitzhugh, G. R. \& W. F. Hettler. 1995. Temperature influence on postovulatory follicle degeneration in Atlantic menhaden, Brevoortia tyrannus. Fishery Bulletin, 93: 568-572.

Forward R. B., J. S. Burke, D. Rittschof \& J. M. Welch. 1996. Photoresponses of larval Atlantic menhaden (Brevoortia tyrannus Latrobe) in offshore and estuarine waters: implications for transport. Journal of Experimental Marine Biology and Ecology, 5: 123-135.

Franklin, A. B., T. M. Shenk, D. R. Anderson \& K. P. Burnham. 2001. Statistical model selection: an alternative to null hypothesis testing. Pp 75-90. In: Shenk, T. M. \& A. M. Franklin (Eds.). Modeling in natural resources management: development, interpretation, and application. Washington, Island Press.

Fuiman, L. A. 2002. Special considerations of fish eggs and larvae. Pp. 1-32. In: Fuiman, L. A. \& R.G. Wegner (Eds.) Fishery Science. The unique contributions of early life stages. Blackwell Science Ltd.

García, G., J. Vergara, \& V. Gutiérrez. 2008. Phylogeography of the Southwestern Atlantic menhaden genus Brevoortia (Clupeidae, Alosinae). Marine Biology, 155: 325-336.

Garman, G. C. \& S. A. Macko. 1998. Contribution of marinederived organic matter to an Atlantic coast, freshwater, tidal stream by anadromous clupeid fishes. Journal of the North American Benthological Society, 17: 277-285.

González-Castro, M., J. M. Díaz de Astarloa, M. B. Cousseau, D. E. Figueroa, S. M. Delpiani, D. O. Bruno, J. M. Guzonni, G. E. Blasina \& M. Y. Deli Antoni. 2009a. Fish composition in a south-western Atlantic temperate coastal lagoon: spatialtemporal variation and relationships with environmental variables. Journal of the Marine Biological Association of the United Kingdom, 89: 593-604.

González-Castro, M., V. Abachian \& R. G. Perrotta. 2009b. Age and growth of the striped mullet, Mugil platanus (Actinopterygii, Mugilidae), in a southwestern Atlantic coastal lagoon $\left(37^{\circ} 32^{\prime} \mathrm{S}-57^{\circ} 19^{\prime} \mathrm{W}\right)$ : a proposal for a life-history model. Journal of Applied Ichthyolgy, 25: 61-66. 
González-Castro, M., G. J. Macchi \& M. B. Cousseau. 2011. Studies on reproduction of the mullet Mugil platanus Günther, 1880 (Actinopterygii, Mugilidae) from the Mar Chiquita coastal lagoon, Argentina: similarities and differences with related species. Italian Journal of Zoology, 78: 343-353.

González-Castro, M., S. M. Delpiani, D. O., Bruno \& J. M. Díaz de Astarloa. 2013. First occurrence of the Patagonian blennie, Eleginops maclovinus (Cuvier, 1830) and the silverside Odontesthes smitti (Lahille, 1929), in a temperate south-western Atlantic coastal lagoon. Journal of Applied Ichthyology, 29: 940-942.

González-Castro, M., J. J. Rosso, N. A. Lajud, D. L. Castellini \& J. M. Díaz de Astarloa. 2015. Occurrence of Cyprinus carpio (Linnaeus, 1758) in a World Biosphere Reserve, the Mar Chiquita Coastal Lagoon (Argentina). Journal of Applied Ichthyology, 31:749-751.

Hempel, G. 1979. Early life history of marine fish. The egg stage. Washington Sea Grant, University of Washington Press, Seattle, Washington, 70p.

Hunter, J. R., N. C. H. Lo, \& R. J. H. Leong. 1985. Batch Fecundity in Multiple Spawning Fishes. Pp. 67-77. In: Lasker, R. (Ed.). An egg production method for estimating spawning biomass of pelagic fish: application to the northern anchovy (Engraulis mordax). U. S. Departament of Commerce.

Iribarne, O. (Ed.). 2001. Reserva de Biosfera Mar Chiquita: características físicas, biológicas y ecológicas. Mar del Plata, Argentina: Editorial Martín, 320p.

Isla F. I. 1995. Coastal lagoons. Pp. 241-272. In: G. M. E. Perillo (Ed.). Geomorphology and sedimentology of estuaries. Developments in sedimentology 53. Amsterdam, Elsevier Science.

Johnson, J. B. \& K. S. Omland. 2004. Model selection in ecology and evolution. Trends in Ecology \& Evolution, 19: 101-108.

Kartas F. \& J. P. Quignard. 1984. La Fécondité des poissons téléostéens. Paris, Masson. 121p.

Lasta, C. A., \& J. D. de Ciechomski. 1988. Primeros resultados de los estudios sobre la distribución de huevos y larvas de peces en Bahía Samborombón en relación a temperatura y salinidad. Publicaciones de la Comisión Técnica Mixta del Frente Marítimo, 4: 133-141.

Lopez-Cazorla, A. 1985. Edad, crecimiento y comportamiento migratorio de Brevoortia aurea (Agassiz, 1829) (Osteichthyes, Clupeidae) de Bahía Blanca (Argentina). Investigación Pesquera, 49: 297-314.

López, S., E. Mabragaña, J. M. Díaz de Astarloa \& M. GonzálezCastro. 2013. Reproductive studies of Anchoa marinii (Actinopterygii, Engraulidae) in the nearby-coastal area of Mar Chiquita coastal lagoon (Buenos Aires, Argentina). Neotropical Ichthyology, 13: 221-228.
Macchi, G .J. \& M. E. Acha. 2000. Spawning frequency and batch fecundity of Brazilian menhaden, Brevoortia aurea, in the Río de la Plata estuary off Argentina and Uruguay. Fishery Bulletin, 98: 283-289.

Munroe, T. A. \& M. S. Nizinski. 2002. Clupeidae. Herrings (shads, menhadens). Pp. 804-830. In: Carpenter, K. E. (Ed.). The living marine resources of the Western Central Atlantic. Volume 2: Bony fishes part 1 (Acipenseridae to Grammatidae). Roma, FAO Species Identification Guide for Fishery Purposes and American Society of Ichthyologists and Herpetologists Special Publication $N^{\circ} 5$.

Nikolsky, G. 1963. The ecology of fishes. London, Academic press. 352 p.

Pájaro, M., G. J. Macchi, \& R. P. Sánchez. 1997. Fecundidad y frecuencia reproductiva de las poblaciones bonaerense $\mathrm{y}$ patagónica de la anchoíta argentina (Engraulis anchoita). Revista de Investigación y Desarrollo Pesquero, 11: 19- 38.

Reta R., P. Martos, G. M. E. Perillo, M. C. Piccolo \& A. Ferrante. 2001. Características hidrográficas del estuario de la Laguna Mar Chiquita. Pp. 31-52. In: Iribarne O (Ed.). Reserva de Biosfera Mar Chiquita: Características físicas, biológicas y ecológicas. Mar del Plata, Editorial Martín.

Roa, R., B. Ernst \& F. Tapia. 1999. Estimation of size at sexual maturity: an evaluation of analytical and resampling procedures. Fishery Bulletin, 97: 570-580.

Rodrigues, A. K., G. J. Macchi, E. M. Acha. \& M. I. Militelli. 2008. Spawning and fecundity of Jenyns's sprat, Ramnogaster arcuata, a winter spawner in the temperate waters of the Río de la Plata estuary, Argentina-Uruguay. Journal of the Marine Biological Association of the United Kingdom, 88: 423-429.

Segura, V. \& J. M. Díaz de Astarloa. 2004. Análisis osteológico del género Brevoortia (Actinopterygii, Clupeidae) en el Atlántico suroccidental. Revista de Biología Marina y Oceanografía, 39: 37-52.

Vaughan D. S., K. W. Shertzer \& J. W. Smith. 2007. Gulf menhaden (Brevoortia patronus) in the U.S. Gulf of Mexico: Fishery characteristics and biological reference points for management. Fisheries Research, 83: 263-275.

Venables, W. N. \& B. D. Ripley. 2002. Modern applied statistics with S-Plus. 4. Ed. New York, Springer, 584p.

Whitehead, P. J. P. 1985. Vol. 7. Clupeoid fishes of the world (suborder CLUPEOIDEI). An annotated and illustrated catalogue of the herrings, sardines, pilchards, sprats, anchovies and wolf-herrings. Part I: Chirocentridae, Clupeidae and Pristigasteridae. FAO Fisheries Synopsis, 125, 303p.

Submitted May 12, 2015 Accepted January 20, 2016 by Clarice Fialho 